\title{
Hypertension as a prognostic factor in metastatic renal cell carcinoma treated with tyrosine kinase inhibitors: a systematic review and meta-analysis
}

\author{
Yu Liu ${ }^{\dagger}$, Liang Zhou ${ }^{\dagger}$, Yuntian Chen ${ }^{\dagger}$, Banghua Liao, Donghui Ye, Kunjie Wang ${ }^{*}$ [D and Hong Li
}

\begin{abstract}
Background: Conflicting evidence exists regarding the effect of hypertension on the prognosis of metastatic renal cell carcinoma (mRCC) patients treated with tyrosine kinase inhibitors (TKls). This study aimed to assess the predictive value of TKIs-induced hypertension in patients with mRCC.

Methods: This study was registered in PROSPERO (CRD42019129593). PubMed, Embase, Web of Science and the Cochrane Library database were searched with terms: "renal cell carcinoma", "hypertension", "blood pressure", "tyrosine kinase inhibitor", "sunitinib", "axitinib", "sorafenib" and "pazopanib" until March 21, 2019. Hazard Ratios (HR) and 95\% confidence intervals (Cl) for progression-free survival (PFS) or overall survival (OS) were extracted and analyzed with Stata 15.0 software. Heterogeneity was assessed using the $I^{2}$ value. Meta-regression, subgroup analysis and sensitivity analysis were also performed to explore heterogeneity. Publication bias was assessed with funnel plots and precisely assessed by Egger's and Begg's tests. The quality of evidence of outcomes was generated according to the Grading of Recommendations Assessment, Development, and Evaluation (GRADE).

Results: A total of 4661 patients from 22 studies were included in the study. The results showed that the increase of blood pressure was an effective predictor for longer PFS (HR $\left.=0.59,95 \% \mathrm{Cl}: 0.48-0.71, p<0.001 ; I^{2}=77.3 \%\right)$ and OS (HR $\left.=0.57,95 \% \mathrm{Cl}: 0.45-0.70, p<0.001 ; I^{2}=77.4 \%\right)$ of patients with mRCC. Subgroup analysis revealed that patients receiving sunitinib and pazopanib could have longer PFS and OS.

Conclusions: This study indicated that TKIs-induced hypertension may be a good predictor for better prognosis of patients with $\mathrm{mRCC}$ receiving TKls treatment, especially using sunitinib or pazopanib.
\end{abstract}

Keywords: Metastatic renal cell carcinoma, Tyrosine kinase inhibitors, Hypertension, Prognosis, Meta-analysis

\section{Background}

Renal cell carcinoma (RCC) is the 9th most common cancer in men and 14th most common cancer in women worldwide [1]. Its incidence $(3-6 / 100,000)$ and mortality $(1.2-2.5 / 100,000)$ are increasing rapidly, which has a great negative effect on our society $[2,3]$. In addition, about $25-30 \%$ of patients have evidence of metastasis upon its diagnosis [4]. Now, vascular endothelial growth

\footnotetext{
*Correspondence: wangki@scu.edu.cn

†Yu Liu, Liang Zhou and Yuntian Chen contributed equally to this work and should be considered as co-first authors

Department of Urology, Institute of Urology (Laboratory of Reconstructive Urology), West China Hospital, Sichuan University, No.37 Guo Xue Xiang, Chengdu, Sichuan 610041, People's Republic of China
}

factor receptor tyrosine kinase inhibitors (TKIs), like sunitinib, pazopanib, sorafenib or axitinib, are the favored medicine for metastatic RCC (mRCC). Several clinical trials showed that response to TKIs was uncertain (objective response rate was 31-67.4\%) [5-8], which indicated the existence of wide inter-individual variation and the lack of reliable factors for predicting the outcomes of mRCC patients. Therefore, a big challenge faced by urologists is how to predict the prognosis of mRCC patients receiving TKIs more precisely.

The occurrence of several adverse events (AEs) during TKIs therapy, such as hypertension, hand-foot syndrome or hypothyroidism, were shown to be correlated with the

(c) The Author(s). 2019 Open Access This article is distributed under the terms of the Creative Commons Attribution 4.0 International License (http://creativecommons.org/licenses/by/4.0/), which permits unrestricted use, distribution, and 
longer median progression-free survival (PFS) and overall survival (OS) of mRCC patients [9]. Hypertension during TKIs therapy was very common, with incidence ranging from 22 to $81 \%[9,10]$. Recently, a study found that RCC patients with longer median PFS ( $>5.3$ months) demonstrated a significantly higher incidence of high-grade hypertension (a treatment-associated adverse event) than those with shorter PFS [11]. It indicated that TKIs-induced hypertension may be associated with improved prognosis $[12,13]$. However, others reported insignificant results $[14,15]$. In 2014, a systematic review and meta-analysis reported that the occurrence of hypertension due to sorafenib therapy may be associated with improved prognosis of patients with cancer. However, this study did not specifically focus on the mRCC patients. Thus, the association between TKIsinduced hypertension and prognosis of $\mathrm{mRCC}$ is still controversial. In the present study, we attempt to conduct a systematic review and meta-analysis to assess the predictive value of the TKIs-induced hypertension for PFS and OS in patients with mRCC during TKIs therapy.

\section{Methods}

\section{Data sources and literature search strategy}

We conducted this meta-analysis in accordance with the Preferred Reporting Items for Systematic Reviews and Meta-Analysis statement. This study was registered in PROSPERO (CRD42019129593). A literature search was performed in the following databases: PubMed, Embase, Web of Science and the Cochrane Library database. The latest search was performed on March 21, 2019. The search keywords were (renal cell carcinoma) AND [(tyrosine kinase inhibitor) OR sunitinib OR axitinib OR sorafenib OR pazopanib] AND [hypertension OR (blood pressure). The resulted literatures were further scanned by Endnote X7 (Thomson Corporation, Canada) to exclude duplications followed by title and abstract screening. In addition, we manually searched the references of the literatures for additional eligible studies.

\section{Inclusion and exclusion criteria}

Studies were included in our meta-analysis if the following criteria were met: 1) mRCC patients were treated with TKIs; 2) studies compared Hazard Ratios (HR) between patients with or without TKIs-induced hypertension for PFS or OS.

Studies were excluded based on the following criteria: 1) reviews, meta-analysis, letters, comments, case reports or conference abstracts; 2) duplicated studies and repeated analysis; 3) studies lacking sufficient data for HR and their 95\% confidence intervals (CI);4) studies included mRCC patients received different therapeutic regimen, such as TKIs or radiotherapy.

\section{Quality of original studies}

We assessed the quality of the 22 included studies using the Newcastle-Ottawa Scale (NOS). The total score was 9 stars. Studies awarded 7-9 stars were rated as high-quality, 5-6 stars as moderate-quality, and $<5$ stars as low-quality.

\section{Data extraction}

Eligible studies were read thoroughly and carefully to extract the following information, including first author, year, region, sample size, male/female ratio, mean age, histology, number of disease sites, prior nephrectomy, Memorial Sloan Kettering Cancer Center (MSKCC) score, Eastern Cooperative Oncology Group performance status (ECOG PS) score, definition of hypertension, type of analysis (univariate or multivariate), study design (prospective or retrospective), type of TKIs. The primary outcome was HR and 95\% CI between patients with or without hypertension for PFS and secondary one for OS. The definition of PFS was time from initiation of TKIs therapy to disease progression or death. OS was defined as time from initiation of TKIs therapy to death. If a study provided both univariate and multivariate analysis results, the multivariate analysis would be selected to achieve higher accuracy. Any discrepancies were resolved by discussion with the third reviewer.

\section{Data synthesis and statistical analysis}

Data were extracted and analyzed with Stata 15.0 software (Stata Corporation, College Station, TX, USA). $P$ value $<$ 0.05 was considered statistically significant. A merged HR greater than 1 indicated a poorer prognosis for $\mathrm{mRCC}$ patients. Heterogeneity was assessed using the $\mathrm{I}^{2}$. We considered $\mathrm{I}^{2}>50 \%$ as an indicator of substantial heterogeneity. A random effects model and a fixed effects model were applied for $\mathrm{I}^{2}>50 \%$ and $\mathrm{I}^{2}<50 \%$, respectively. Then, to determine which factors may contribute to heterogeneity, univariate and multivariate meta-regression analysis were performed. The possible factors were year, sample size, gender, mean age, country, ECOG PS, MSKCC score, histology, prior nephrectomy, Number of disease sites, type of analysis (univariate, multivariate), study design (retrospective, prospective), type of TKIs. Then, subgroup analysis was performed to investigate whether different sample size could explain the heterogeneity and whether relationship between hypertension and PFS or OS still exist in different TKIs subgroups. Factor with $P$ value $<0.05$ meant that it may be the source of heterogeneity. We did sensitivity analysis to find if some original studies may mainly contribute to the heterogeneity. Publication bias was assessed with funnel plots and precisely assessed by Egger's and Begg's tests.

\section{Quality of evidence}

The quality of evidence of the predictive effect of TKIsinduced hypertension for the outcomes in mRCC patients 


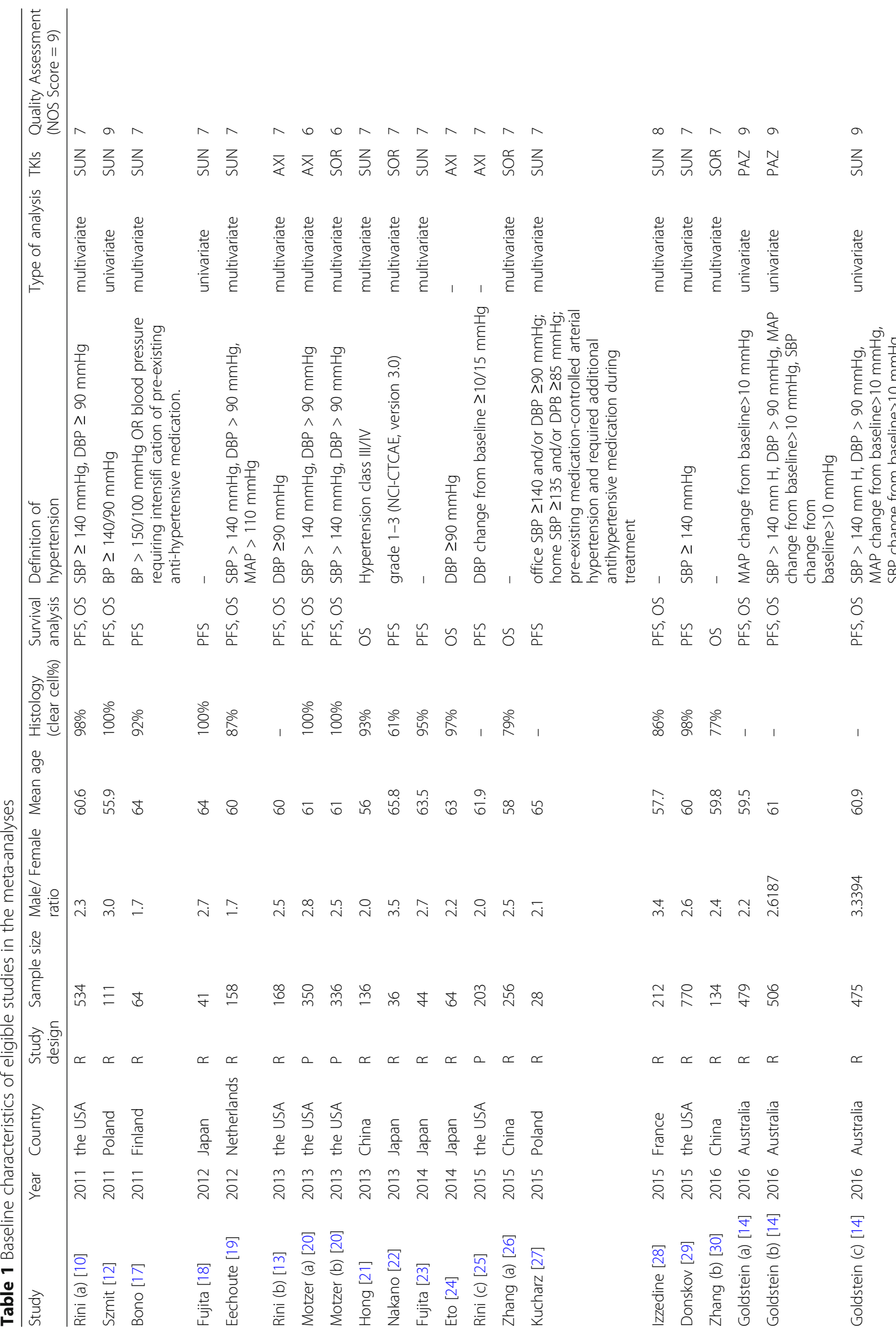




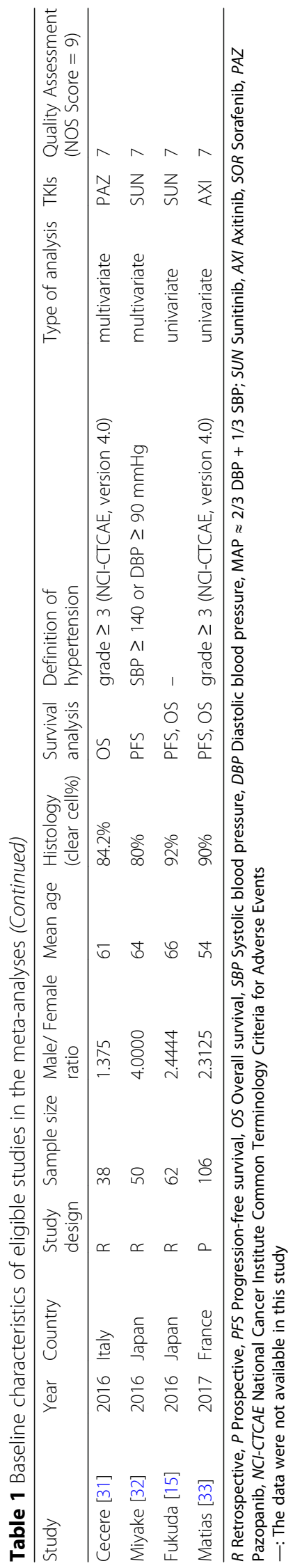


was assessed according to the Grading of Recommendations Assessment, Development, and Evaluation (GRADE) [16].

\section{Results}

\section{Study selection}

The searching process is shown in Additional file 1: Figure S1. A total of 982 studies were searched in the database. We excluded 345 duplicated articles. After screening title and abstract, 26 relevant studies were identified. In addition, three relevant studies were obtained from the references and seven articles were excluded due to lack of HR and 95\% CI for PFS or OS. Finally, 22 studies were selected for the metaanalysis.

\section{Study characteristics and quality}

The baseline characteristics of these studies were demonstrated in Table 1. All the studies were published between 2011 and 2017. Of them, 3 were prospective and 19were retrospective. The sample size ranged from 28 to 770 patients. The total number of included patients was 4661 and hypertension occurred in 2932 (62.9\%). The male/female ratio included in each study ranged from 1.4 to $3.5 \%$, and the median age of the study patients was between 54 years and 66 years. The histology of most RCC is clear cell (61-100\%). Most patients had received nephrectomy, cytokine therapy, targeted therapy or radiation therapy. Among the 22 studies providing HR, four reported univariate $H R$, which did not adjust for the potential confounding factors. The standard of hypertension or BP increasement during TKIs therapy varied between studies, including systolic blood pressure (SBP) $\geq 140 / 135 \mathrm{mmHg}$, diastolic blood pressure (DBP) $\geq 90 / 85 \mathrm{mmHg}$, mean arterial blood pressure (MAP) > $110 \mathrm{mmHg}$, an increase in BP (SBP, DBP, MAP) > 10/15 mmHg from baseline, or grades of hypertension according to National Cancer Institute Common Terminology Criteria for Adverse Events Version 3.0 or $4.0[34,35]$. The quality of the studies varied from a NOS score of 6 to 9 , most of which were high-quality (Table 2).

Table 2 Newcastle-Ottawa scale score of the reviewed studies

\begin{tabular}{|c|c|c|c|c|c|c|c|c|c|}
\hline \multirow[t]{2}{*}{ Study } & \multicolumn{4}{|l|}{ Selection (4 stars) } & \multirow{2}{*}{$\begin{array}{l}\text { Comparability } \\
\text { (2 stars) }\end{array}$} & \multicolumn{3}{|c|}{ Outcome (3 stars) } & \multirow{2}{*}{$\begin{array}{l}\text { Total } \\
\text { score }\end{array}$} \\
\hline & $\begin{array}{l}\text { Representativeness } \\
\text { of the hypertensive } \\
\text { cohort }\end{array}$ & $\begin{array}{l}\text { Selection of the } \\
\text { non-hypertensive } \\
\text { cohort }\end{array}$ & $\begin{array}{l}\text { Ascertainment of } \\
\text { hypertension }\end{array}$ & $\begin{array}{l}\text { Demonstration } \\
\text { that outcome } \\
\text { of interest was } \\
\text { not present at } \\
\text { start of study }\end{array}$ & & $\begin{array}{l}\text { Assessment } \\
\text { of outcome }\end{array}$ & $\begin{array}{l}\text { Was follow up } \\
\text { long enough } \\
\text { for outcomes } \\
\text { to occur? }\end{array}$ & $\begin{array}{l}\text { Adequacy of } \\
\text { follow up of } \\
\text { cohort }\end{array}$ & \\
\hline Rini (a) & $\star$ & $\star$ & $\star$ & $\star$ & - & $\star$ & $\star$ & $\star$ & 7 \\
\hline Szmit & $\star$ & $\star$ & $\star$ & $\star$ & $\star \star$ & $\star$ & $\star$ & $\star$ & 9 \\
\hline Bono & $\star$ & $\star$ & $\star$ & $\star$ & - & $\star$ & $\star$ & $\star$ & 7 \\
\hline Fujita & $\star$ & $\star$ & $\star$ & $\star$ & - & $\star$ & $\star$ & $\star$ & 7 \\
\hline Eechoute & $\star$ & $\star$ & $\star$ & $\star$ & - & $\star$ & $\star$ & $\star$ & 7 \\
\hline Rini (b) & $\star$ & $\star$ & $\star$ & $\star$ & - & $\star$ & $\star$ & $\star$ & 7 \\
\hline Motzer & - & $\star$ & $\star$ & $\star$ & - & $\star$ & $\star$ & $\star$ & 6 \\
\hline Hong & $\star$ & $\star$ & $\star$ & $\star$ & - & $\star$ & $\star$ & $\star$ & 7 \\
\hline Nakano & $\star$ & $\star$ & $\star$ & $\star$ & - & $\star$ & $\star$ & $\star$ & 7 \\
\hline Fujita & $\star$ & $\star$ & $\star$ & $\star$ & - & $\star$ & $\star$ & $\star$ & 7 \\
\hline Eto & $\star$ & $\star$ & $\star$ & $\star$ & - & $\star$ & $\star$ & $\star$ & 7 \\
\hline Rini (c) & $\star$ & $\star$ & $\star$ & $\star$ & - & $\star$ & $\star$ & $\star$ & 7 \\
\hline Zhang (a) & $\star$ & $\star$ & $\star$ & $\star$ & - & $\star$ & $\star$ & $\star$ & 7 \\
\hline Kucharz & $\star$ & $\star$ & $\star$ & $\star$ & - & $\star$ & $\star$ & $\star$ & 7 \\
\hline Izzedine & $\star$ & $\star$ & $\star$ & $\star$ & $\star$ & $\star$ & $\star$ & $\star$ & 8 \\
\hline Donskov & $\star$ & $\star$ & $\star$ & $\star$ & - & $\star$ & $\star$ & $\star$ & 7 \\
\hline $\begin{array}{l}\text { Zhang } \\
\text { (b) }\end{array}$ & $\star$ & $\star$ & $\star$ & $\star$ & - & $\star$ & $\star$ & $\star$ & 7 \\
\hline Goldstein & $\star$ & $\star$ & $\star$ & $\star$ & $\star \star$ & $\star$ & $\star$ & $\star$ & 9 \\
\hline Miyake & $\star$ & $\star$ & $\star$ & $\star$ & - & $\star$ & $\star$ & $\star$ & 7 \\
\hline Fukuda & $\star$ & $\star$ & $\star$ & $\star$ & - & $\star$ & $\star$ & $\star$ & 7 \\
\hline Matias & $\star$ & $\star$ & $\star$ & $\star$ & - & $\star$ & $\star$ & $\star$ & 7 \\
\hline
\end{tabular}

一: The data were not available in this study 


\section{Relationship between TKIs-induced hypertension and PFS or OS of $\mathrm{mRCC}$ patients}

HR of PFS and OS were quantitatively synthesized and data were shown in Figs. 1 and 2. Elevated blood pressure was positively correlated with better PFS (HR $=0.59,95 \%$ CI: $\left.0.48-0.71, p<0.001 ; \mathrm{I}^{2}=77.3 \%\right)$ and $\mathrm{OS}(\mathrm{HR}=0.57$, 95\% CI: $\left.0.45-0.70, p<0.001 ; \mathrm{I}^{2}=77.4 \%\right)$. It meant that patients developing hypertension may have a lower mortality risk and live longer without progression of $\mathrm{mRCC}$. The heterogeneity was obvious between studies.

\section{Meta-regression analysis}

Univariate meta-regression analysis was performed for PFS and results were showed in Table 3. Among the variables above mentioned, only sample size (Adjusted $R^{2}=$ $27.34 \%, P=0.019)$ might contribute to the inter-study heterogeneity, while others did not $(P=0.052-0.942)$.

Multivariate meta-regression analysis revealed that $P$ value of sample size changed to 0.025 . The overall adjusted $\mathrm{R}^{2}$ was $74.84 \%(P=0.239)$, which meant that all these factors together could account for $74.84 \%$ of heterogeneity.

\section{Subgroup analysis}

Subgroup analysis for PFS revealed that sample size could not change the subgroup heterogeneity significantly $\left(\mathrm{I}^{2}=72.1\right.$ and $75 \%$ ) (Table 3 ). In addition, for different TKIs, only patients with TKIs-induced hypertension in sunitinib subgroup ( $\mathrm{HR}=0.47,95 \%$ CI: 0.34-0.64, $\mathrm{p}<0.001$ ) and pazopanib subgroup (HR $=0.79,95 \%$ CI: $0.66-0.94, p=0.01$ ) could have longer PFS. However, development of hypertension in four different TKIs subgroups could all predict longer OS, including sunitinib subgroup $(\mathrm{HR}=0.48,95 \% \mathrm{CI}$ : $0.30-0.78, p=0.003)$, pazopanib subgroup $(\mathrm{HR}=$ 0.73, 95\% CI: $0.55-0.97, p=0.032$ ), axitinib subgroup $(\mathrm{HR}=0.62,95 \% \mathrm{CI}: 0.43-0.88, p=0.007)$ and sorafenib subgroup $(\mathrm{HR}=0.66,95 \% \mathrm{CI}: 0.48-0.91, p=$ 0.010) (Figs. 1 and 2).

\section{Sensitivity analysis}

As shown in Fig. 3, study of "Szmit", "Motzer (a)" and "Donskov" could affect the heterogeneity for PFS. We excluded these studies and found that $\mathrm{I}^{2}$ decreased to $44.6 \%(P=0.03)$, with pooled $\mathrm{HR}=0.665$

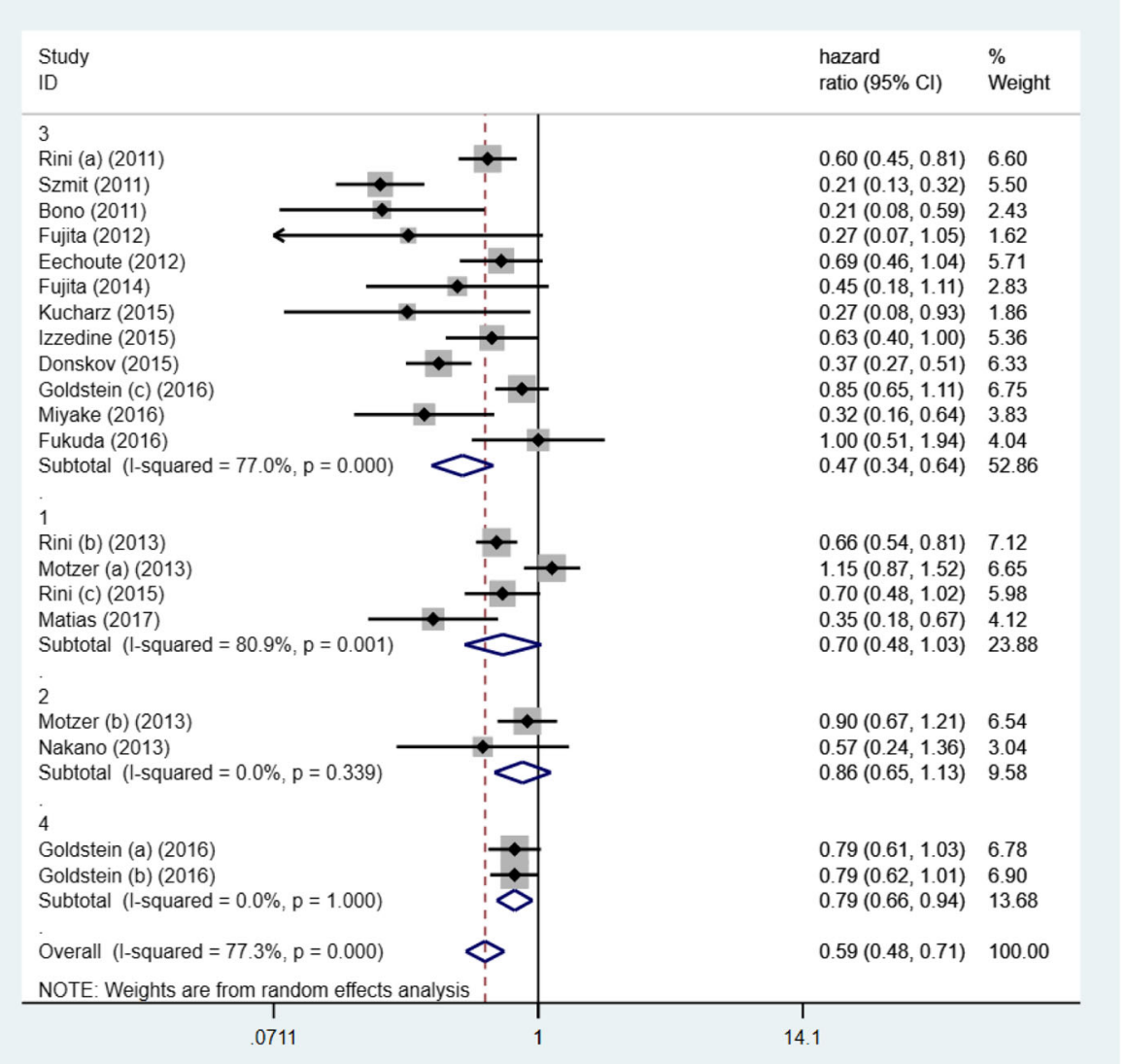

Fig. 1 Forest plot reflects the association between TKls -induced hypertension and oncologic outcomes (progression free survival) in different TKls subgroups (1: axitinib; 2: sorafenib; 3: sunitinib; 4: pazopanib) 


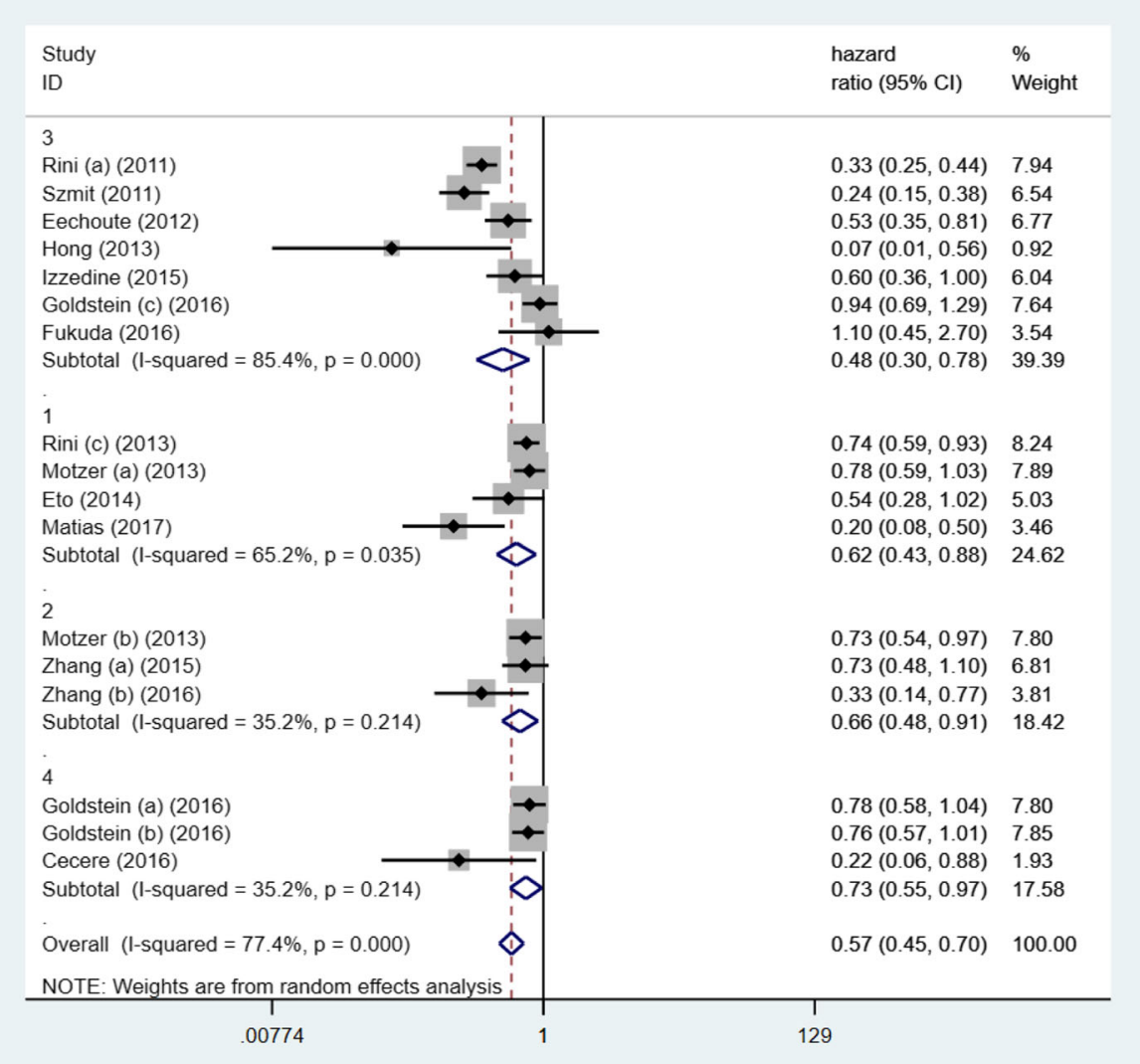

Fig. 2 Forest plot reflects the association between TKIs-induced hypertension and oncologic outcomes (overall survival) in different TKls subgroups (1: axitinib; 2: sorafenib; 3: sunitinib; 4: pazopanib)

(0.579-0.764, $P=0.025)$. Then, we reviewed these studies carefully to find something they had in common. Interestingly, most of the mRCC patients in these three studies had failed one previous cytokine immunotherapy. Maybe it was the reason for high heterogeneity.

\section{Publication bias}

We assessed the publication bias with funnel plot and Egger's and Begg's tests (Fig. 4). The shape of funnel plots was not symmetric. The Egger's and Begg's tests were further performed. The results indicated significant publication bias for studies, with merged PFS (Begg's test, $P=0.015$; Egger's test, $P=0.028$ ) and merged OS (Begg's test, $P=0.026$; Egger's test, $P=$ $0.085)$.

\section{Evaluation of the quality of evidence according to GRADE system}

The assessment of the quality of evidence was performed for PFS and OS which were critical in evaluating the outcome of mRCC patients. The quality of evidence of PFS and OS was both "very low" due to retrospective studies, publication bias and high heterogeneity (Table 4 ).

\section{Discussion}

This meta-analysis and systematic review investigated whether TKIs-induced hypertension can predict the prognosis of patients suffering from mRCC. AEs, like hypothyroidism, though shown to be a good predictor of PFS or OS, was usually diagnosed later than hypertension $[17,36]$. Thus, it would be better if we can predict the prognosis of $\mathrm{mRCC}$ patients based on the TKIs-induced hypertension. It will help urologists decide whether patients should continue this TKIs therapy or not, which may help patients get more suitable treatments as soon as possible. Based on 22 original studies, our results showed that the occurrence of hypertension during treatment may predict better survival for mRCC, with longer PFS and OS. Additionally, when it comes to different TKIs, sunitinib or pazopanib therapy were both associated with longer PFS and OS.

The mechanisms of hypertension induced by TKIs are complicated. First, activation of VEGF receptor-2 via 
Table 3 Meta-regression and subgroup analyses of pooled hazard ratios for progression-free survival

\begin{tabular}{|c|c|c|c|c|c|c|c|c|c|c|c|}
\hline \multirow[t]{2}{*}{ Subgroup } & \multicolumn{7}{|c|}{ Meta-regression } & \multicolumn{2}{|c|}{ Pooled HR of PFS } & \multicolumn{2}{|c|}{ Heterogeneity } \\
\hline & $\begin{array}{l}\text { No. of } \\
\text { studies }\end{array}$ & Coefficient & $\begin{array}{l}\text { Standard } \\
\text { error }\end{array}$ & T value & $P$ value & $\mathrm{Tau}^{2}$ & Adjusted $\mathrm{R}^{2}$ & $\mathrm{HR}(95 \% \mathrm{Cl})$ & $P$ value & $\overline{1^{2}}$ & $P$ value \\
\hline Year & 20 & 0.060 & 0.228 & 0.26 & 0.795 & 0.182 & $-8.86 \%$ & & & & \\
\hline $2011-2014$ & & & & & & & & $0.56(0.40-0.77)$ & $<0.001$ & $83.00 \%$ & $<0.001$ \\
\hline $2015-2017$ & & & & & & & & $0.61(0.48-0.77)$ & $<0.001$ & $73.60 \%$ & $<0.001$ \\
\hline Sample size & 20 & 0.507 & 0.197 & 2.57 & 0.019 & 0.122 & $27.34 \%$ & & & & \\
\hline$<200$ & & & & & & & & $0.43(0.30-0.61)$ & $<0.001$ & $72.10 \%$ & $<0.001$ \\
\hline$\geq 200$ & & & & & & & & $0.73(0.60-0.89)$ & 0.002 & $75 \%$ & $<0.001$ \\
\hline Gender (male/female ratio) & 20 & -0.117 & 0.228 & -0.51 & 0.614 & 0.177 & $-5.64 \%$ & & & & \\
\hline$<2.5$ & & & & & & & & $0.66(0.53-0.82)$ & $<0.001$ & $54.50 \%$ & 0.025 \\
\hline$\geq 2.5$ & & & & & & & & $0.55(0.40-0.74)$ & $<0.001$ & $84.70 \%$ & $<0.001$ \\
\hline Mean age & 20 & 0.320 & 0.264 & 2.21 & 0.241 & 0.156 & $6.69 \%$ & & & & \\
\hline$<60$ & & & & & & & & $0.44(0.23-0.86)$ & 0.015 & $89.40 \%$ & $<0.001$ \\
\hline$\geq 60$ & & & & & & & & $0.64(0.53-0.78)$ & $<0.001$ & $69.70 \%$ & $<0.001$ \\
\hline Country & 20 & 0.168 & 0.301 & 0.56 & 0.584 & 0.173 & $-3.31 \%$ & & & & \\
\hline the USA, Europe & & & & & & & & $0.60(0.49-0.74)$ & $<0.001$ & $81.40 \%$ & $<0.001$ \\
\hline Asia & & & & & & & & $0.51(0.31-0.83)$ & 0.006 & $39.50 \%$ & 0.158 \\
\hline ECOG PS (grade 0\%) & 20 & 0.036 & 0.133 & 0.27 & 0.79 & 0.182 & $-8.59 \%$ & & & & \\
\hline$<0.5$ & & & & & & & & $0.35(0.14-0.89)$ & 0.028 & $87.20 \%$ & $<0.001$ \\
\hline$\geq 0.5$ & & & & & & & & $0.64(0.52-0.79)$ & $<0.001$ & $71.90 \%$ & $<0.001$ \\
\hline MSKCC score (favorable\%) & 20 & 0.231 & 0.111 & 2.08 & 0.052 & 0.123 & $26.74 \%$ & & & & \\
\hline$<0.25$ & & & & & & & & $0.43(0.21-0.87)$ & 0.019 & $76 \%$ & 0.002 \\
\hline$\geq 0.25$ & & & & & & & & $0.86(0.73-1.02)$ & 0.076 & $40.30 \%$ & 0.137 \\
\hline Histology (clear cell\%) & 20 & -0.139 & 0.126 & -1.11 & 0.283 & 0.166 & $1.11 \%$ & & & & \\
\hline$<0.9$ & & & & & & & & $0.53(0.39-0.71)$ & $<0.001$ & $29.30 \%$ & 0.226 \\
\hline$\geq 0.9$ & & & & & & & & $0.51(0.33-0.79)$ & 0.002 & $87.90 \%$ & $<0.001$ \\
\hline Prior nephrectomy (\%) & 20 & -0.162 & 0.129 & -1.25 & 0.226 & 0.166 & $1.16 \%$ & & & & \\
\hline$<0.9$ & & & & & & & & $0.52(0.40-0.67)$ & 0.296 & $17.50 \%$ & $<0.001$ \\
\hline$\geq 0.9$ & & & & & & & & $0.52(0.33-0.81)$ & $<0.001$ & $89.30 \%$ & 0.005 \\
\hline No. of disease sites (1\%) & 20 & -0.253 & 0.139 & -1.81 & 0.086 & 0.144 & $13.81 \%$ & & & & \\
\hline$<0.2$ & & & & & & & & $0.41(0.28-0.60)$ & $<0.001$ & $62.40 \%$ & 0.047 \\
\hline$\geq 0.2$ & & & & & & & & $0.52(0.37-0.74)$ & $<0.001$ & 0 & 0.594 \\
\hline Type of analysis & 20 & -0.030 & 0.231 & -0.13 & 0.898 & 0.182 & $-8.91 \%$ & & & & \\
\hline Univariate & & & & & & & & $0.59(0.42-0.82)$ & 0.002 & $82.70 \%$ & $<0.001$ \\
\hline Multivariate & & & & & & & & $0.58(0.46-0.75)$ & $<0.001$ & $74.50 \%$ & $<0.001$ \\
\hline Study design & 20 & 0.343 & 0.257 & 1.34 & 0.198 & 0.157 & $6.32 \%$ & & & & \\
\hline Retrospective & & & & & & & & $0.54(0.44-0.67)$ & $<0.001$ & $74.90 \%$ & $<0.001$ \\
\hline Prospective & & & & & & & & $0.77(0.53-1.12)$ & 0.175 & $76.20 \%$ & 0.006 \\
\hline Type of TKIs & 20 & -0.073 & 0.114 & -0.64 & 0.942 & 0.178 & $-10.49 \%$ & & & & \\
\hline Axitinib & & & & & & & & $0.70(0.48-1.03)$ & 0.07 & $80.90 \%$ & 0.001 \\
\hline Sorafenib & & & & & & & & $0.86(0.65-1.13)$ & 0.277 & 0 & 0.339 \\
\hline Sunitinib & & & & & & & & $0.47(0.34-0.64)$ & $<0.001$ & $77.90 \%$ & $<0.001$ \\
\hline Pazopanib & & & & & & & & $0.79(0.66-0.94)$ & 0.010 & 0 & 1.000 \\
\hline
\end{tabular}




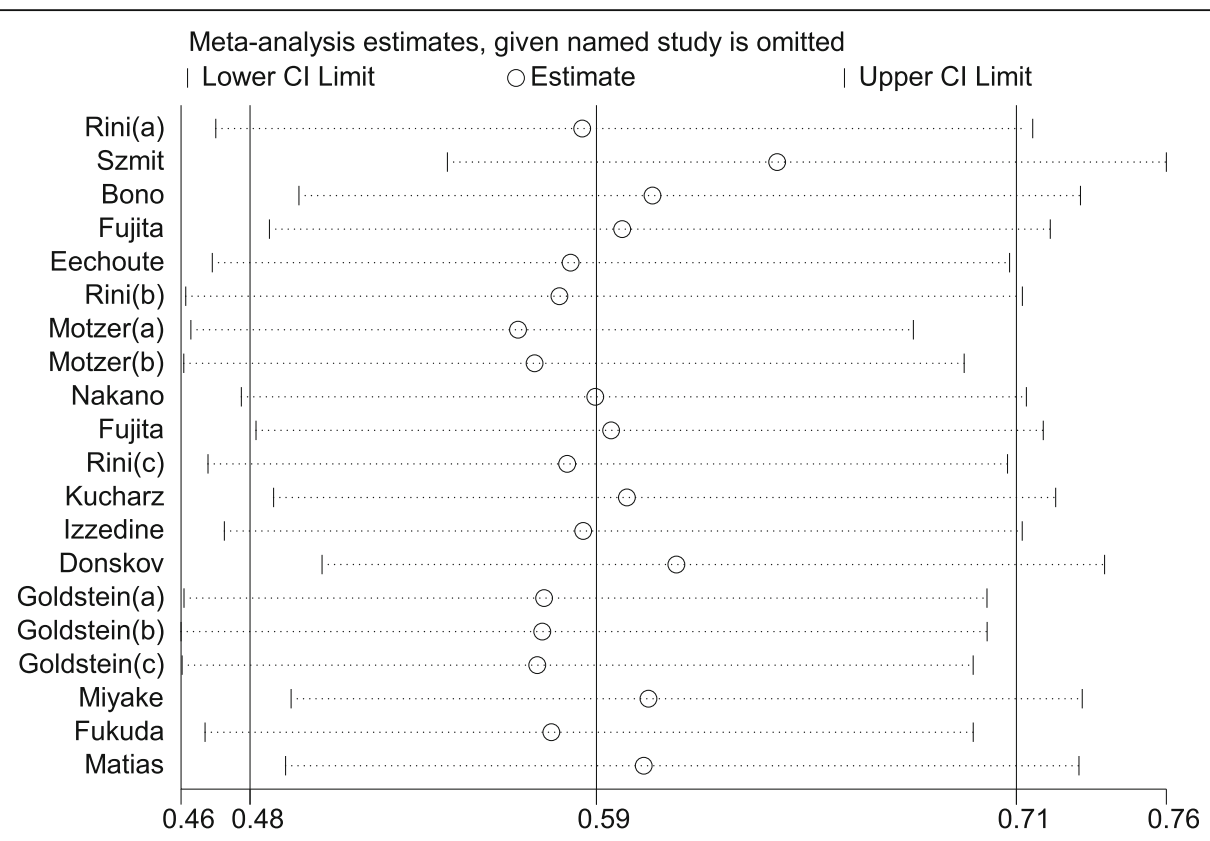

Fig. 3 Sensitivity analysis of progression free survival for the evaluation of potential heterogeneity

phosphoinositide 3-kinase and its downstream serine protein kinase Akt can stimulate endothelium-derived nitric oxide synthase, leading to the production of nitric oxide (NO). Therefore, the inhibition of VEGF receptor might lead to a decrease in NO bioavailability, followed by vasoconstriction and increased blood pressure (BP) [17, 37-39]. Second, plasma vasoconstrictor endothelin1 , a vasoconstrictor produced by the endothelium, also increased in patients or rats receiving sunitinib [40-42]. Third, NO is also involved in the control of renal and glomerular hemodynamics, tubuloglomerular feedback response, release of renin and sympathetic transmitters, tubular ion transport. As a result, reduction of NO can also result in renal water and sodium retention, leading to hypertension [43]. TKIs may also directly cause renal injury and proteinuria, which could play a role in longlasting hypertension [44]. Finally, hypertension may also result from structural or functional vascular rarefaction [45-47]. VEGF is also crucial in the maintenance of endothelial viability $[48,49]$. Therefore, the inhibition of VEGF and PDGF receptors can induce endothelial cell apoptosis, reduction in capillary density, vascular diameter and microvascular flow, and thus increase the blood pressure.

The reason why TKIs-induced hypertension might be a prognostic factor in patients with $\mathrm{mRCC}$ is still
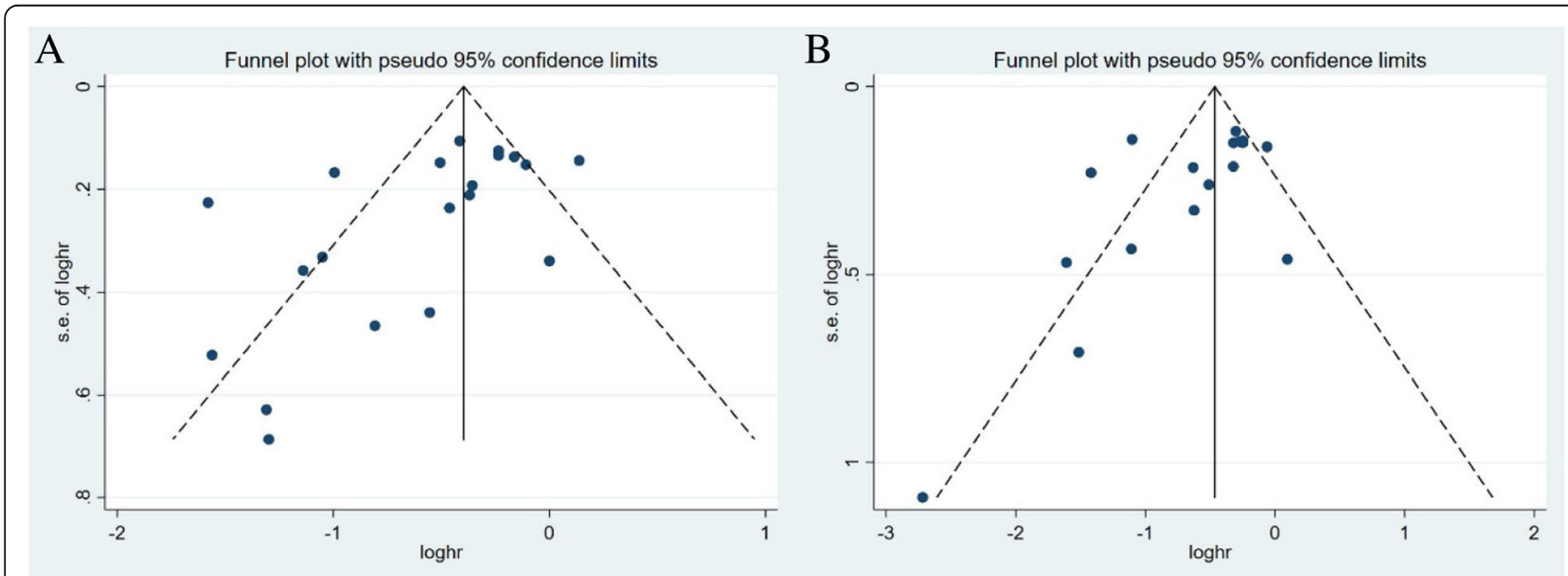

Fig. 4 Funnel plot for publication bias. a progression free survival, b overall survival 


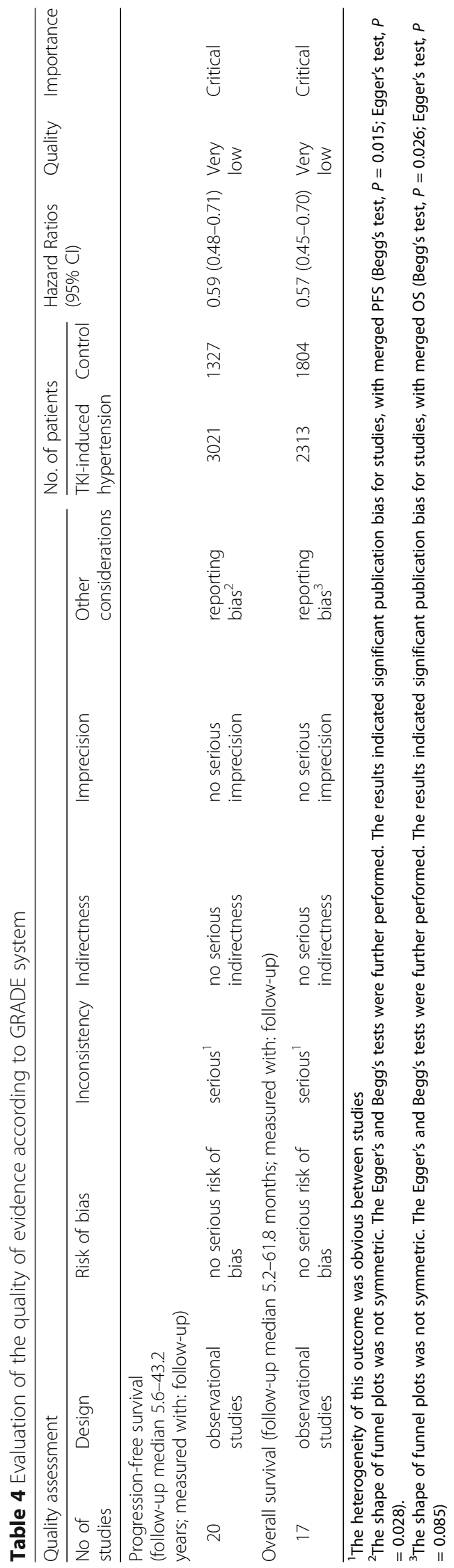


not quite clear. The anticarcinogenic effect of TKIs relies on the block of VEGF receptor, which may also lead to hypertension as above mentioned. Thus, when TKIs inhibit the progress of $\mathrm{mRCC}$ and prolong the PFS or OS of patients, hypertension may occur at the same time. It may be the reason why the rise of blood pressure could indicate a better prognosis in mRCC patients.

Of note, the intention of therapy is not to drive all patients into a hypertensive state. On the contrary, when hypertension occurs, patients should receive antihypertensive therapy as soon as possible. Additionally, despite the PFS and OS of mRCC patients have prolonged because of TKIs therapy, few comparable benefits have been described in terms of the quality of life [50, 51]. An innovative study that compared sunitinib with pazopanib to evaluate patient preferences suggested that the toxicity profile may have an impact on quality of life and the choice of treatment when two comparable options are on offer [52]. In addition, sunitinib-induced hypertension may be associated with cardiotoxicity or reversible posterior leukoencephalopathy [53-55]. Thus, the panel of National Cancer Institute of the USA had several recommendations for mRCC patients received TKIs [56]. First, urologists should recognize the preexisting hypertension prior to therapy or actively monitor BP throughout treatment. Early use of antihypertensive medication is necessary when high blood pressure occurs, and it is critical for maintaining dose intensity and improving a patient's quality of life simultaneously [56]. If possible, the goal of management is to reduce BP below 140/90 $\mathrm{mmHg}$. It was also suggested that there was no need to reduce the dose of antihypertensive medication because it did not compromise efficacy of TKIs [57]. Some evidence indicated that using Angiotensin receptor blockers (ARBs) or angiotensin-I-converting enzyme inhibitors may even protect against cancer [58-60]. ARBs were shown to induce apoptosis and inhibit the proliferation of RCC cells in vitro [28]. Thus, some randomized prospective studies could be carried out to see if it is better to use more than one drugs with different antihypertensive mechanisms, which may improve the prognosis [12]. Second, doctors should assess the risk of potential cardiovascular complications.

Several underlying limitations of the study should be presented. First, most eligible studies were retrospective, though with high NOS scores. Second, the reciprocal correlation between the hypertension and other AEs should be noted. Patients with more than one adverse event of any grade had longer PFS and OS [61]. Thus, further studies are needed to analyze the relationship between several adverse events and mRCC. Third, obvious inter-study heterogeneity was observed in this meta analysis, which may be due to different therapies mRCC patients had received before, such as cytokine immunotherapy. In addition, a publication bias was detected in this study. The potential reason may be that studies with non-significant results were not published. High heterogeneity and publication bias weakened the quality of evidence, which may be improved by more randomized prospective trials.

However, our analysis also has some advantages. First, we conducted this review with enough data available for extraction by a comprehensive and robust search strategy. Second, we applied a rigorous inclusion/exclusion criterion. Additionally, most of the studies operated multivariable analysis, which could eliminate the co-factors affecting the PFS and OS of mRCC patients.

\section{Conclusions}

In summary, our analysis of currently available clinical evidence suggests that TKIs-induced hypertension may predict longer PFS and OS in patients with $\mathrm{mRCC}$ during TKIs therapy, especially using sunitinib or pazopanib.

\section{Additional file}

Additional file 1: Figure S1. Flow chart showing literature searching process of meta-analysis. The search keywords are (renal cell carcinoma) AND [(tyrosine kinase inhibitor) OR sunitinib OR axitinib OR sorafenib OR pazopanib] AND [hypertension OR (blood pressure). (DOCX 140 kb)

\section{Abbreviations}

AEs: Adverse events; BP: Blood pressure; Cl: Confidence intervals; DBP: Diastolic blood pressure; ECOG PS: Eastern Cooperative Oncology Group performance status; GRADE: Grading of Recommendations Assessment, Development and Evaluation; HR: Hazard Ratios; MAP: Mean arterial blood pressure; mRCC: Metastatic renal cell carcinoma; MSKCC: Memorial Sloan Kettering Cancer Center; NO: Nitric oxide; NOS: Newcastle-Ottawa Scale; OS: Overall survival; PFS: Progression-free survival; RCC: Renal cell carcinoma; SBP: Systolic blood pressure; TKIs: Tyrosine kinase inhibitors

\section{Acknowledgements}

Not applicable.

\section{Authors' contributions}

LY was mainly responsible for the design of the work, the acquisition and analysis of data and manuscript writing. ZL carried out the acquisition of data. CYT and YDH participated in the analysis of data. LBH, WKJ and LH revised the manuscript. All authors read and approved the final manuscript.

\section{Funding}

This study was funded by 1.3.5 project for disciplines of excellence, West China Hospital, Sichuan University (ZY2016104), Project of Sichuan Provincial Health Department (ZH2017-101) and The National Natural Science Fund of China (81800667).

\section{Availability of data and materials}

The datasets used and/or analysed during the current study available from the corresponding author on reasonable request. 


\section{Ethics approval and consent to participate}

All analyses were based on previous published studies. Thus, no ethical approval and patient consent are required.

\section{Consent for publication}

Not applicable.

\section{Competing interests}

The authors declare that they have no competing interests.

Received: 29 October 2018 Accepted: 28 May 2019

Published online: 07 June 2019

\section{References}

1. Znaor A, Lortet-Tieulent J, Laversanne M, Jemal A, Bray F. International variations and trends in renal cell carcinoma incidence and mortality. Eur Urol. 2015;67(3):519-30.

2. Wong MCS, Goggins WB, Yip BHK, Fung FDH, Leung C, Fang Y, Wong SYS, $\mathrm{Ng}$ CF. Incidence and mortality of kidney cancer: temporal patterns and global trends in 39 countries. Sci Rep. 2017;7(1):15698.

3. Rossi SH, Klatte T. Epidemiology and screening for renal. cancer. 2018;36(9): 1341-53.

4. Gupta K, Miller JD, Li JZ, Russell MW, Charbonneau C. Epidemiologic and socioeconomic burden of metastatic renal cell carcinoma (mRCC): a literature review. Cancer Treat Rev. 2008;34(3):193-205.

5. Naito S, Tsukamoto T, Murai M, Fukino K, Akaza H. Overall survival and good tolerability of long-term use of sorafenib after cytokine treatment: final results of a phase II trial of sorafenib in Japanese patients with metastatic renal cell carcinoma. BJU Int. 2011;108(11):1813-9.

6. Tomita Y, Shinohara N, Yuasa T, Fujimoto H, Niwakawa M, Mugiya S, Miki T, Uemura H, Nonomura N, Takahashi M, et al. Overall survival and updated results from a phase II study of sunitinib in Japanese patients with metastatic renal cell carcinoma. Jpn J Clin Oncol. 2010;40(12):1166-72.

7. Motzer RJ, Hutson TE, Tomczak P, Michaelson MD, Bukowski RM, Rixe O, Oudard S, Negrier S, Szczylik C, Kim ST, et al. Sunitinib versus interferon alfa in metastatic renal-cell carcinoma. N Engl J Med. 2007;356(2):115-24.

8. Rixe O, Bukowski RM, Michaelson MD, Wilding G, Hudes GR, Bolte O, Motzer $\mathrm{RJ}$, Bycott P, Liau KF, Freddo J, et al. Axitinib treatment in patients with cytokine-refractory metastatic renal-cell cancer: a phase II study. Lancet Oncol. 2007;8(11):975-84.

9. Ravaud A, Schmidinger M. Clinical biomarkers of response in advanced renal cell carcinoma. Ann Oncol. 2013;24(12):2935-42.

10. Rini BI, Cohen DP, Lu DR, Chen I, Hariharan S, Gore ME, Figlin RA, Baum MS, Motzer RJ. Hypertension as a biomarker of efficacy in patients with metastatic renal cell carcinoma treated with sunitinib. J Natl Cancer Inst. 2011;103(9):763-73.

11. Li Y, Li S, Zhu Y, Liang X, Meng H, Chen J, Zhang D, Guo H, Shi B. Incidence and risk of sorafenib-induced hypertension: a systematic review and metaanalysis. J Clin Hypertens (Greenwich, Conn). 2014;16(3):177-85.

12. Szmit S, Langiewicz P, ZInierek J, Nurzynski P, Zaborowska M, Filipiak KJ, Opolski G, Szczylik C. Hypertension as a predictive factor for survival outcomes in patients with metastatic renal cell carcinoma treated with sunitinib after progression on cytokines. Kidney Blood Press Res. 2012;35(1): $18-25$.

13. Rini BI, Garrett M, Poland B, Dutcher JP, Rixe O, Wilding G, Stadler WM, Pithavala YK, Kim S, Tarazi J, et al. Axitinib in metastatic renal cell carcinoma: results of a pharmacokinetic and pharmacodynamic analysis. J Clin Pharmacol. 2013:53(5):491-504.

14. Goldstein D, Rosenberg JE, Figlin RA, Townsend RR, McCann L, Carpenter C, Pandite L. Is change in blood pressure a biomarker of pazopanib and sunitinib efficacy in advanced/metastatic renal cell carcinoma? Eur J Cancer (Oxford, England : 1990). 2016;53:96-104.

15. Fukuda $H$, Kondo T, lida S, Takagi T, Tanabe K. Treatment-related deterioration of renal function is associated with the antitumor efficacy of sunitinib in patients with metastatic renal cell carcinoma. Urol Oncol. 2016; 34(8):338.e331-9.

16. Guyatt G, Oxman AD, Akl EA, Kunz R, Vist G, Brozek J, Norris S, Falck-Ytter Y, Glasziou P, DeBeer $H$, et al. GRADE quidelines: 1. Introduction-GRADE evidence profiles and summary of findings tables. J Clin Epidemiol. 2011;64:383-94.
17. Bono P, Rautiola J, Utriainen T, Joensuu H. Hypertension as predictor of sunitinib treatment outcome in metastatic renal cell carcinoma. Acta Oncol (Stockholm, Sweden). 2011;50(4):569-73.

18. Fujita T, Iwamura M, Ishii D, Tabata K, Matsumoto K, Yoshida K, Baba S. Creactive protein as a prognostic marker for advanced renal cell carcinoma treated with sunitinib. Int J Urol. 2012;19(10):908-13.

19. Eechoute $K$, van der Veldt AA, Oosting S, Kappers MH, Wessels JA, Gelderblom H, Guchelaar HJ, Reyners AK, van Herpen CM, Haanen JB, et al. Polymorphisms in endothelial nitric oxide synthase (eNOS) and vascular endothelial growth factor (VEGF) predict sunitinib-induced hypertension. Clin Pharmacol Ther. 2012;92(4):503-10.

20. Motzer R, Escudier B, Tomczak P, Hutson TE, Michaelson MD, Negrier S, Oudard S, Gore ME, Tarazi J, Hariharan S, et al. Axitinib versus sorafenib as second-line treatment for advanced renal cell carcinoma: overall survival analysis and updated results from a randomised phase 3 trial. Lancet Oncol. 2013;14(6):552-62.

21. Hong YP, Yao XD, Zhu Y, Ye DW, Shi GH, Zhang SL, Dai B, Zhang HL, Shen YJ, Zhu YP, et al. Exploratory analysis of the effect of toxicity of sunitinib on the clinical outcome of patients with advanced renal cell carcinoma. Zhonghua Yi Xue Za Zhi. 2013:93(36):2880-3.

22. Nakano K, Komatsu K, Kubo T, Natsui S, Nukui A, Kurokawa S, Kobayashi M, Morita T. Hand-foot skin reaction is associated with the clinical outcome in patients with metastatic renal cell carcinoma treated with sorafenib. Jpn J Clin Oncol. 2013;43(10):1023-9.

23. Fujita T, Wakatabe Y, Matsumoto K, Tabata K, Yoshida K, Iwamura M. Leukopenia as a biomarker of sunitinib outcome in advanced renal cell carcinoma. Anticancer Res. 2014:34(7):3781-7.

24. Eto $M$, Uemura $H$, Tomita $Y$, Kanayama $H$, Shinohara $N$, Kamei $Y$, Fujii $Y$, Umeyama Y, Ozono S, Naito S, et al. Overall survival and final efficacy and safety results from a Japanese phase II study of axitinib in cytokinerefractory metastatic renal cell carcinoma. Cancer Sci. 2014;105(12):1576-83.

25. Rini BI, Melichar B, Fishman MN, Oya M, Pithavala YK, Chen Y, Bair AH, Grunwald V. Axitinib dose titration: analyses of exposure, blood pressure and clinical response from a randomized phase II study in metastatic renal cell carcinoma. Ann Oncol. 2015;26(7):1372-7.

26. Zhang HL, Qin XJ, Wang HK, Gu WJ, Ma CG, Shi GH, Zhou LP, Ye DW. Clinicopathological and prognostic factors for long-term survival in Chinese patients with metastatic renal cell carcinoma treated with sorafenib: a single-center retrospective study. Oncotarget. 2015;6(34):36870-83.

27. Kucharz J, Dumnicka P, Kuzniewski M, Kusnierz-Cabala B, Herman RM, Krzemieniecki K. Co-occurring adverse events enable early prediction of progression-free survival in metastatic renal cell carcinoma patients treated with sunitinib: a hypothesis-generating study. Tumori. 2015;101(5):555-9.

28. Izzedine H, Derosa L, Le Teuff G, Albiges L, Escudier B. Hypertension and angiotensin system inhibitors: impact on outcome in sunitinib-treated patients for metastatic renal cell carcinoma. Ann Oncol. 2015;26(6):1128-33.

29. Donskov F, Michaelson MD, Puzanov I, Davis MP, Bjarnason GA, Motzer RJ, Goldstein D, Lin X, Cohen DP, Wiltshire R, et al. Sunitinib-associated hypertension and neutropenia as efficacy biomarkers in metastatic renal cell carcinoma patients. Br J Cancer. 2015;113(11):1571-80.

30. Zhang Y, Li Y, Cai Y, Wang K, Li H. Efficacy of sorafenib correlates with Memorial Sloan-Kettering Cancer Center (MSKCC) risk classification and bone metastasis in Chinese patients with metastatic renal cell carcinoma. Cell Oncol (Dordr). 2016;39(1):15-21.

31. Cecere SC, Rossetti S, Cavaliere C, Della Pepa C, Di Napoli M, Crispo A, lovane G, Piscitelli R, Sorrentino D, Ciliberto G, et al. Pazopanib in metastatic renal Cancer: a "real-world" experience at National Cancer Institute "Fondazione G. Pascale". Front Pharmacol. 2016;7:287.

32. Miyake M, Kuwada M, Hori S, Morizawa Y, Tatsumi Y, Anai S, Hosokawa $Y$, Hayashi $Y$, Tomioka A, Otani $T$, et al. The best objective response of target lesions and the incidence of treatment-related hypertension are associated with the survival of patients with metastatic renal cell carcinoma treated with sunitinib: a Japanese retrospective study. BMC Res Notes. 2016;9:79.

33. Matias M, Le Teuff G, Albiges L, Guida A, Brard C, Bacciarelo G, Loriot Y, Massard C, Lassau N, Fizazi K, et al. Real world prospective experience of axitinib in metastatic renal cell carcinoma in a large comprehensive cancer Centre. Eur J Cancer (Oxford, England: 1990). 2017;79:185-92.

34. Trotti A, Colevas AD, Setser A, Rusch V, Jaques D, Budach V, Langer C, Murphy B, Cumberlin R, Coleman CN, et al. CTCAE v3.0: development of a comprehensive grading system for the adverse effects of cancer treatment. Semin Radiat Oncol. 2003;13(3):176-81. 
35. Chen AP, Setser A, Anadkat MJ, Cotliar J, Olsen EA, Garden BC, Lacouture ME. Grading dermatologic adverse events of cancer treatments: the common terminology criteria for adverse events version 4.0. J Am Acad Dermatol. 2012;67(5):1025-39.

36. Buda-Nowak A, Kucharz J, Dumnicka P, Kuzniewski M, Herman RM, Zygulska AL, Kusnierz-Cabala B. Sunitinib-induced hypothyroidism predicts progression-free survival in metastatic renal cell carcinoma patients. Med Oncol (Northwood, London, England). 2017;34(4):68.

37. Aparicio-Gallego G, Blanco M, Figueroa A, Garcia-Campelo R, ValladaresAyerbes M, Grande-Pulido E, Anton-Aparicio L. New insights into molecular mechanisms of sunitinib-associated side effects. Mol Cancer Ther. 2011; 10(12):2215-23.

38. Hayman SR, Leung N, Grande JP, Garovic VD. VEGF inhibition, hypertension, and renal toxicity. Curr Oncol Rep. 2012;14(4):285-94.

39. Robinson ES, Khankin EV, Karumanchi SA, Humphreys BD. Hypertension induced by vascular endothelial growth factor signaling pathway inhibition: mechanisms and potential use as a biomarker. Semin Nephrol. 2010;30(6):591-601.

40. Merkus D, Sorop O, Houweling B, Boomsma F, van den Meiracker AH, Duncker DJ. NO and prostanoids blunt endothelin-mediated coronary vasoconstrictor influence in exercising swine. Am J Phys Heart Circ Phys. 2006:291(5):H2075-81.

41. Kappers MH, van Esch JH, Sluiter W, Sleijfer S, Danser AH, van den Meiracker $\mathrm{AH}$. Hypertension induced by the tyrosine kinase inhibitor sunitinib is associated with increased circulating endothelin-1 levels. Hypertension (Dallas, Tex : 1979). 2010;56(4):675-81.

42. Kappers MH, Smedts FM, Horn T, van Esch JH, Sleijfer S, Leijten F, Wesseling $\mathrm{S}$, Strevens $\mathrm{H}$, Jan Danser $\mathrm{AH}$, van den Meiracker $\mathrm{AH}$. The vascular endothelial growth factor receptor inhibitor sunitinib causes a preeclampsia-like syndrome with activation of the endothelin system. Hypertension (Dallas, Tex : 1979). 2011;58(2):295-302

43. Zou AP, Cowley AW Jr. Role of nitric oxide in the control of renal function and salt sensitivity. Curr Hypertens Rep. 1999;1(2):178-86.

44. Khan G, Golshayan A, Elson P, Wood L, Garcia J, Bukowski R, Rini B. Sunitinib and sorafenib in metastatic renal cell carcinoma patients with renal insufficiency. Ann Oncol. 2010;21:1618-22.

45. Lacouture ME, Reilly LM, Gerami P, Guitart J. Hand foot skin reaction in cancer patients treated with the multikinase inhibitors sorafenib and sunitinib. Ann Oncol. 2008;19(11):1955-61.

46. Steeghs N, Gelderblom H, Roodt JO, Christensen O, Rajagopalan P, Hovens M, Putter H, Rabelink TJ, de Koning E. Hypertension and rarefaction during treatment with telatinib, a small molecule angiogenesis inhibitor. Clin Cancer Res. 2008;14(11):3470-6.

47. Hubner N, Yagil C, Yagil Y. Novel integrative approaches to the identification of candidate genes in hypertension. Hypertension (Dallas, Tex: 1979). 2006;47(1):1-5.

48. Rees ML, Khakoo AY. Molecular mechanisms of hypertension and heart failure due to antiangiogenic cancer therapies. Heart Fail Clin. 2011;7(3):299-311.

49. Lee S, Chen TT, Barber CL, Jordan MC, Murdock J, Desai S, Ferrara N, Nagy A, Roos KP, Iruela-Arispe ML. Autocrine VEGF signaling is required for vascular homeostasis. Cell. 2007;130(4):691-703.

50. Cella D, Pickard AS, Duh MS, Guerin A, Mishagina N, Antras L, Neary MP, McCann L, Hodge R, Sternberg CN. Health-related quality of life in patients with advanced renal cell carcinoma receiving pazopanib or placebo in a randomised phase III trial. Eur J Cancer (Oxford, England: 1990). 2012;48(3):311-23.

51. Bukowski R, Cella D, Gondek K, Escudier B. Effects of sorafenib on symptoms and quality of life: results from a large randomized placebo-controlled study in renal cancer. Am J Clin Oncol. 2007;30(3):220-7.

52. Escudier B, Porta C, Bono P, Powles T, Eisen T, Sternberg CN, Gschwend JE, De Giorgi U, Parikh O, Hawkins R, et al. Randomized, controlled, doubleblind, cross-over trial assessing treatment preference for pazopanib versus sunitinib in patients with metastatic renal cell carcinoma: PISCES study. J Clin Oncol. 2014;32(14):1412-8.

53. Chu TF, Rupnick MA, Kerkela R, Dallabrida SM, Zurakowski D, Nguyen L, Woulfe K, Pravda E, Cassiola F, Desai J, et al. Cardiotoxicity associated with tyrosine kinase inhibitor sunitinib. Lancet (London, England). 2007;370(9604): 2011-9.

54. Kapiteijn E, Brand A, Kroep J, Gelderblom H. Sunitinib induced hypertension, thrombotic microangiopathy and reversible posterior leukencephalopathy syndrome. Ann Oncol. 2007;18(10):1745-7.
55. Padhy BM, Shanmugam SP, Gupta YK, Goyal A. Reversible posterior leucoencephalopathy syndrome in an elderly male on sunitinib therapy. $\mathrm{Br}$ J Clin Pharmacol. 2011;71(5):777-9.

56. Maitland ML, Bakris GL, Black HR, Chen HX, Durand JB, Elliott WJ, Ivy SP, Leier CV, Lindenfeld J, Liu G, et al. Initial assessment, surveillance, and management of blood pressure in patients receiving vascular endothelial growth factor signaling pathway inhibitors. J Natl Cancer Inst. 2010;102(9):596-604.

57. Langenberg MH, van Herpen CM, De Bono J, Schellens JH, Unger C, Hoekman K, Blum HE, Fiedler W, Drevs J, Le Maulf F, et al. Effective strategies for management of hypertension after vascular endothelial growth factor signaling inhibition therapy: results from a phase II randomized, factorial, double-blind study of Cediranib in patients with advanced solid tumors. J Clin Oncol. 2009;27(36):6152-9.

58. Rao GA, Mann JR, Shoaibi A, Pai SG, Bottai M, Sutton SS, Haddock KS, Bennett CL, Hebert JR. Angiotensin receptor blockers: are they related to lung cancer? J Hypertens. 2013;31(8):1669-75.

59. Lever AF, Hole DJ, Gillis CR, McCallum IR, Mclnnes GT, Mackinnon PL, Meredith PA, Murray LS, Reid JL, Robertson JW. Do inhibitors of angiotensinl-converting enzyme protect against risk of cancer? Lancet (London, England). 1998;352(9123):179-84.

60. Makar GA, Holmes JH, Yang YX. Angiotensin-converting enzyme inhibitor therapy and colorectal cancer risk. J Natl Cancer Inst. 2014;106(2):djt374.

61. lacovelli R, Verri E, Cossu Rocca M, Aurilio G, Cullura D, de Cobelli O, Nole F. Prognostic role of the cumulative toxicity in patients affected by metastatic renal cells carcinoma and treated with first-line tyrosine kinase inhibitors. Anti-Cancer Drugs. 2017;28(2):206-12.

\section{Publisher's Note}

Springer Nature remains neutral with regard to jurisdictional claims in published maps and institutional affiliations.

\section{Ready to submit your research? Choose BMC and benefit from:}

- fast, convenient online submission

- thorough peer review by experienced researchers in your field

- rapid publication on acceptance

- support for research data, including large and complex data types

- gold Open Access which fosters wider collaboration and increased citations

- maximum visibility for your research: over $100 \mathrm{M}$ website views per year

At BMC, research is always in progress.

Learn more biomedcentral.com/submissions 